\title{
The effect of follicle size and cryoprotectants on nuclear maturation and early embryonic development of vitrified - thawed Awassi sheep oocytes (Ovis aries)
}

\author{
Omar Mardenli ${ }^{1 *}$, Mahdi S. Mohammad Al-Kerwi², and Ahmad Y. Alolo ${ }^{1}$ \\ ${ }^{1}$ Deptartment of Animal Production, Faculty of Agriculture, University of Aleppo, Syria \\ ${ }^{2}$ Deptartment of Animal Production, Faculty of Agriculture, University of Al-Qadisiyiah, Iraq
}

\begin{abstract}
MARDENLI, O., M.S. MOHAMMAD AL-KERWI, A. Y.ALOLO: The effect of follicle size and cryoprotectants on nuclear maturation and early embryonic development of vitrified - thawed Awassi sheep oocytes (Ovis aries). Vet. arhiv 91, 483-493, 2021.
\end{abstract}

\section{ABSTRACT}

In this study, two experiments were conducted to study the effect of both the follicle size and the cryoprotectants dimethyl sulfoxide (DMSO) and ethylene glycol (EG) on the main phases of nuclear maturation (Experiment I), cleavage stages and embryo quality (Experiment II) of Awassi sheep oocytes. Follicles were classified into two groups: small follicles (SF) (1-2 mm) and large follicles (LF) (>2 mm). Oocytes were vitrified in three solutions: A (30\% DMSO), B (30\% EG) and C (15\% DMSO and 15\% EG). In Experiment I, the resulting vitrified-thawed oocytes in solution $\mathrm{C}$ achieved the best rates after the control group (fresh), respectively as the rates of maturation, germinal vesicle $(\mathrm{GV})$, metaphase II(M-II), arrest, and lyses were $85.71 \%(\mathrm{P}=0.04), 8.33 \%(\mathrm{P}=0.02), 72.92 \%(\mathrm{P}=0.04)$; $\mathrm{LF}$ group, $15.25 \%(\mathrm{P}=0.04)$, and 5.08\% $(\mathrm{P}=0.04)$; SF group, respectively. In Experiment II, the same group of oocytes achieved the best rates after the control group, as the rates of fertilization, cleavage, 2-16 cell, Type3, blastocyst, and Type1 embryos were 63.28\% $(\mathrm{P}=0.001), 57.46 \%(\mathrm{P}=0.001), 40.38 \%(\mathrm{P}=0.04), 38.46 \%(\mathrm{P}=0.04)$; LF group, $30.00 \%(\mathrm{P}=0.01)$, and SF group 36.67\% ( $\mathrm{P}=0.001)$, respectively, while the vitrified-thawed oocytes in A solution (SF group) reached the highest rate of Type 2 embryo quality $(58.06 \% ; \mathrm{P}=0.01)$. No significant differences were noticed in the germinal vesicle breakdown (GVBD), metaphase I (M-I) and morula stage. Vitrification of oocytes obtained from follicles with a diameter of more than $2 \mathrm{~mm}$ in a cocktail solution of DMSO (15\%) and EG (15\%) led to a significant increase in the yield and quality of the resulting sheep embryos.

Key words: dimethyl sulfoxide; ethylene glycol; follicle size; oocytes; sheep; vitrification

\section{Introduction}

Within the scope of cryopreservation techniques in all cell lines, the process of oocyte cryopreservation is just as important as freezing early embryos, as this procedure is one of the most important solutions to overcome the problem of storing the massive harvest of oocytes obtained from females that are genetically superior and destined for slaughter due to the expiration of their productive period. In fact, the process of oocyte cryopreservation has gone through several stages, starting from programmed slow freezing, down to vitrification (JAVED et al., 2011). Whether in

\footnotetext{
*Corresponding author:

Omar Mardenli, PhD, Faculty of Agriculture, Aleppo University, Syria, Phone: +90 539342 2659; E-mail: omardenli@gmail.com
} 
the case of producing embryos in vitro without freezing, or in the presence of freezing, the concept of the developmental competence of oocytes plays a specific and essential role in the levels of in vitro production. In the freezing scenario of mammal oocytes, and according to the morphological structure of the oocytes, their size and components, there are some basic indicators that seem specific to the survival of the oocytes and their viability following freezing. Among these indicators are cryodamage to the oocytes' spindle, zona pellucida, DNA injury, and embryonic aneuploid (RAJU et al., 2007). As a promising prospect for all cell lines, the vitrification method has become completely dominant. Vitrification is based on several principles, including a high concentration of cryoprotectant agents $\left(\mathrm{CPA}_{\mathrm{S}}\right)$ and variable rates of time in the equilibrium and freezing stages. In order to raise the positive efficiency of vitrification in the viability and survivability of early embryos and oocytes, several practical methods have emerged, perhaps the most important of which is preservation by the Open Pulled Straw (OPS) (VAJTA et al., 1997; GRIZELJ et al., 2009), the Closed Pulled Straw (CPS) (VAJTA et al., 1998), electron microscope grids (MARTINO et al., 1996), cryotops (KUWAYAMA and KATO, 2000), cryoloops (LANE et al., 1999), and minimum drop size methods (YAVIN and ARAV, 2001). Most theories related to vitrification aim to study the interrelationships of $\mathrm{CPA}_{\mathrm{S}}$, their chemical properties, and behaviour in cells. Due to the chemical and molecular properties of both DMSO and EG, these two agents were welcomed with open arms into the freezing world. Both agents are characterized by high permeability and small molecules that have the ability to bind with water molecules. limiting the amount of intracellular and extracellular water, which protects the intracellular organelles (PRENTICE and ANZAR, 2011).

In Syria, the pure Awassi sheep breed constitutes a basic mainstay of the economy due to its excellent meat characteristics, and many countries have been keen to import it for various breeding purposes. In view of the importance of this breed, there was a need recently to establish a genetic bank in order to preserve its valuable genetic resources. Herein, the current study aimed to evaluate the viability, survivability and nuclear maturation of vitrified Awassi sheep oocytes, derived from different follicle sizes by using the cryoprotectants: DMSO, and EG, and their participation in an equal ratio $(1: 1)$ in addition to studying the subsequent development stages and quality of the resulting early embryos.

\section{Material and methods}

Oocyte recovery. Ovaries of Awassi ewes were collected during summer and fall months (breeding season) from local slaughterhouses in Aleppo and Damascus Cities. The ovaries were kept in Dulbecco's Phosphate Buffer Saline (DPBS) and transported immediately (about $1 \mathrm{~h}$ ) to the reproductive biotechnology laboratory of the Animal Production Department at the Faculty of Agriculture in Aleppo City (Fig. 2). To ensure the largest possible number of collected oocytes, cumulus - oocyte complexes (COCs) were collected by aspiration and slicing methods as follows: for each group of follicles, the aspiration method was performed by aspirating the whole follicular fluid from follicles through a sterile 18 -g needle attached to a $5 \mathrm{~mL}$ syringe containing a sterile saline solution. Afterword, the slicing method was applied to the same follicles from which the follicular fluid was aspirated using a surgical blade. The dissected follicles were washed in a Petri dish several times with Tissue Culture Medium - 199 (TCM-199) supplemented with heparin. Next, COCs obtained in both ways were placed together in a Petri dish.

Experimental design.The study included two basic experiments as follows:

Experiment I. This experiment was concieved to study the nuclear maturation of oocytes treated with different concentrations of cryoprotectants following vitrification, in addition to the control group. The nuclear maturation included the passage of the oocytes in four phases: GV, GVBD, M-I and M-II.

Experiment II. In this experiment, all vitrifiedthawed oocytes were used to evaluate the subsequent stages of development, including the IVF and cleavage stages, in addition to studying the embryo quality. 
Cryoprotectants determination. Oocytes were subjected to vitrification using three levels (solutions) of cryoprotectants (A, B and C) in addition to the control group which was without treatment or freezing (Fresh), noting that each solution was composed of two parts: an equilibrium solution (A: $1.5 \mathrm{~mL}$ DMSO; B: $1.5 \mathrm{~mL}$ EG; C: $0.75 \mathrm{~mL}$ DMSO $+0.75 \mathrm{~mL}$ EG) and a vitrification solution (A: $3 \mathrm{~mL}$ DMSO; B: $3 \mathrm{~mL}$ EG; C: $1.5 \mathrm{~mL}$

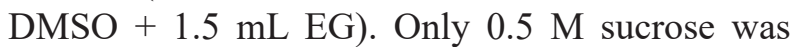
added to ES, so the volume of each solution was finally $10 \mathrm{~mL}$.

Follicle diameter determination. Follicle diameters were measured using a ruler and they were divided into two main groups: SF : $1-2 \mathrm{~mm}$ (small follicles); LF: $>2 \mathrm{~mm}$ (large follicles).

Oocytes cryopreservation. The oocytes were vitrified as described previously by GHORBANI et al. (2012) with minor modifications. Briefly, the oocytes were subjected to ES by keeping them for 8-10 minutes at moderate room temperature (the equilibrium stage), and they were then transferred to VS for exactly 1 minute (the vitrification stage). During that time ( 1 minute), every 6-8 oocytes were put into straw $(0.25 \mathrm{~mm})$ which was closed securely using special devices and plunged immediately into liquid nitrogen. The oocytes were left in liquid nitrogen for seven days (156 hours).

Oocyte thawing (rewarming). Frozen oocytes were thawed in two steps, as described previously by GHORBANI et al. (2012) with minor modifications, as follows: in order to remove the cryoprotectants, the oocytes were transferred into two successive baths containing decreasing concentrations of sucrose and a fixed concentration of fetal calf serum (FCS) ( 20\% FCS $+1 \mathrm{M}$ sucrose; $20 \% \mathrm{FCS}+0.5$ M sucrose), supplemented with TCM-199, so the volume was finally $10 \mathrm{~mL}$ of each solution. The oocytes were placed into the first solution at room temperature $\left(22-25{ }^{\circ} \mathrm{C}\right)$ for $1 \mathrm{~min}$, then transferred to the second solution for $3 \mathrm{~min}$ before they were placed in TCM-199 for an additional $5 \mathrm{~min}$. The oocytes were then cultured in $500 \mathrm{~mL}$ of TCM-199 at $38.8{ }^{\circ} \mathrm{C}$ in the presence of $5 \% \mathrm{CO}_{2}, 5 \% \mathrm{O}_{2}$ and $90 \% \mathrm{~N}_{2}$ at $100 \%$ humidity.
Oocyte nuclear maturation monitoring. Vitrified-thawed and fresh oocytes were placed on glass slides, covered with a cover slip, fixed with aceto-ethanol (acetic acid: ethanol 1:3, V/V), and stained with $1 \%$ aceto-orcein. After drying, the slides were examined under an inverted microscope at high magnification (300× magnifications) with immersion in oil, to investigate the GV, GVBD, M-I and M-II stages (Fig. 1).

In vitro maturation (IVM). Following vitrification, IVM was performed as described previously by SALVADOR et al. (2011) with minor modifications. Briefly, COCs were matured in TCM-199 supplemented with $0.255 \mathrm{mM}$ sodium pyruvate, $10 \%$ heat-treated estrus cow serum, $5 \mu \mathrm{g} /$ $\mathrm{mL}$ FSH, $25 \mathrm{mM}$ Hepes and $100 \mu \mathrm{M}$ cysteamine. The oocytes were incubated for $27 \mathrm{~h}$ at $39{ }^{\circ} \mathrm{C}$ in $5 \% \mathrm{CO} 2$ and $95 \%$ air. Following incubation, the maturation rate was evaluated by observation of the first polar body under the microscope.

Sperm preparation and in vitro fertilization (IVF). Following maturation, presumptive COCs were denuded of the surrounding cumulus cells by transferring to $2 \mathrm{~mL}$ Hepes- Tyrode's Albumin Lactate Pyruvate (Hepes -TALP), vortexed for $1 \mathrm{~min}$, and washed three times in Hepes - TALP, supplemented with $2 \%$ bovine serum albumin (BSA), and twice in IVF-TALP. The oocytes were subjected to Fertil-TALP $(250 \mu \mathrm{L})$. The fertilization medium (TALP) was supplemented with a final concentration of $10 \mu \mathrm{g} / \mathrm{mL}$ heparin-sodium salt, $500 \mu \mathrm{M}$ epinephrine and $250 \mu \mathrm{M}$ penicillamine. Frozen-thawed Awassi ram semen was prepared for IVF according to SALVADOR et al. (2011) with minor modifications. Briefly, after thawing in a water bath at $38{ }^{\circ} \mathrm{C}$ for 30 seconds, the straws were emptied into a centrifuge tube with $4 \mathrm{~mL}$ of Hepes-TALP medium. Next, the resulting aliquot of sperm pellet was resuspended (1:1) with HepesTALP medium. $2 \mathrm{~mL}$ of Hepes-TALP medium were added to $50 \mu \mathrm{L}$ of aliquots of spermatozoa. Following swimming-up, $0.5 \mathrm{~mL}$ of the sperm suspension was collected and centrifuged at 200 $\mathrm{x} \mathrm{g}$ for $10 \mathrm{~min}$. The resulting sperm pellet was resuspended with heparin, containing $(100 \mu \mathrm{g} / \mathrm{mL})$ Hepes-TALP medium, and incubated for $45 \mathrm{~min}$ at $38.5{ }^{\circ} \mathrm{C}$. The sperm concentration was assessed 


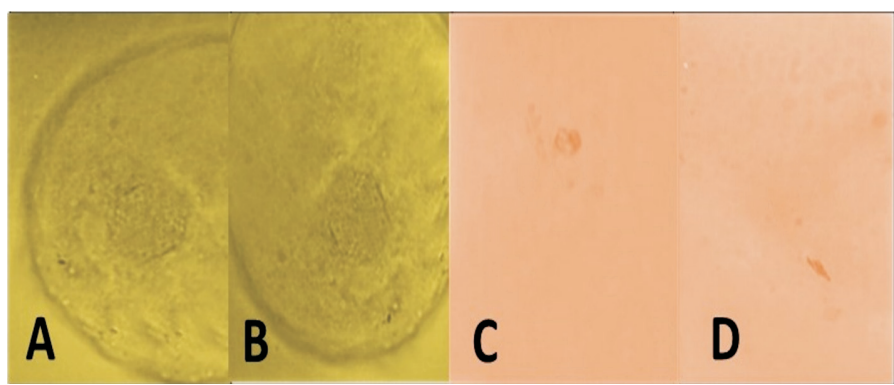

Fig. 1. The four phases of nuclear maturation of Awassi sheep oocytes in Experiment-I (A:GV; B:GVBD; C:M-I; D:M-II).

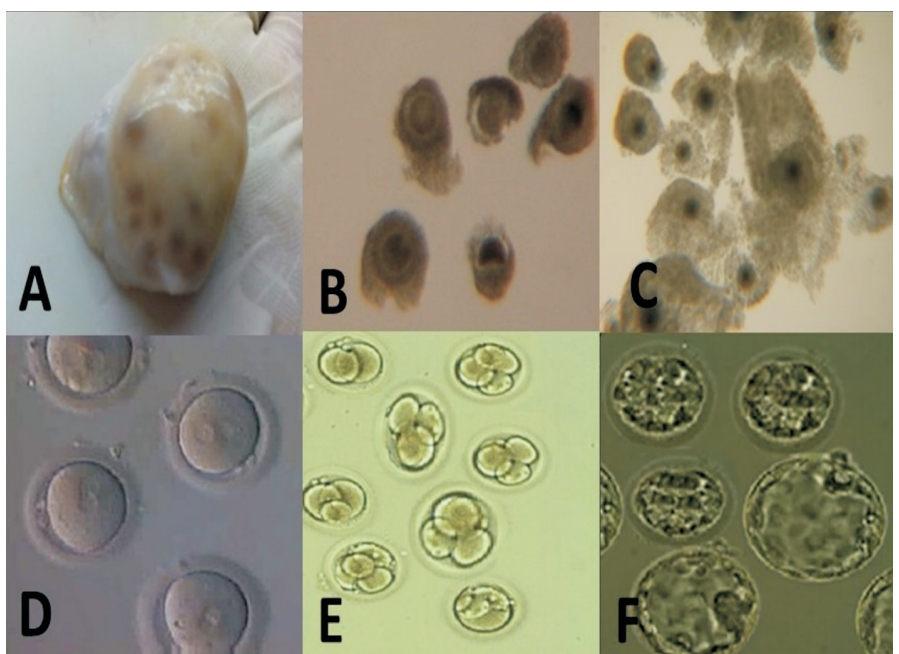

Fig. 2. An Awassi sheep ovary containing follicles with different sizes (A), Awassi sheep COCs in GV stage (B), GVBD stage (C), IVF (D) and cleavage stages (E:different stages of blastomeres; F: morula and blastocyst stages) (Experiment-II).

in a haemocytometer to give a final concentration of $3 \times 10^{9}$ sperms $/ \mathrm{mL}$. The resulting spermatozoa were added to each fertilization well to obtain a final concentration of $1.5 \times 10^{6}$ spermatozoa $/ \mathrm{mL}$. The fertilization stage lasted $17 \mathrm{~h}$ under $5 \% \mathrm{CO}_{2}$ in air with maximum humidity $(>95 \%)$ of $38.5{ }^{\circ} \mathrm{C}$. Following incubation, the resulting zygotes were rinsed with Phosphate Buffer Saline (PBS) and subjected to microscopic examination in order to investigate the second polar body (Fig. 2).

In vitro culture (IVC). Zygotes were transferred into the culture wells and cultured in TCM-199 under mineral oil in a humidified atmosphere of 5\% $\mathrm{CO}_{2}, 5 \% \mathrm{O}_{2}$ and $90 \% \mathrm{~N}_{2}$ at $38.5{ }^{\circ} \mathrm{C}$ for six days (SILVA et al., 2010) (Fig. 2).

Embryo grading. According to their external appearance, the embryos were classified into three main groups, according to WINTNER et al. (2017) with some modifications, as follows:

Type 1: embryonic cells largely of equal size; no fragmentation seen.

Type 2: embryonic cells of equal size; minor fragmentation only.

Type 3: embryonic cells of equal or unequal size; fragmentation is moderate to severe.

Reagents. The chemicals used were from Sigma Chemical Co (St. Louis, USA) unless otherwise mentioned.

Statistical analysis. Pearson's Chi-square of contingency tables and the exact Fisher test were used to analyze the data (IVM, lyses, arrest, IVF, cleavage stages, and embryo type) between the groups of vitrification cryoprotectants solutions and follicle size classes using SAS, 14.3 software package (2017). 
O. Mardenli et al.: The effect of follicle size and cryoprotectants on nuclear maturation and early embryonic development of vitrified - thawed Awassi sheep oocytes (Ovis aries)

\section{Results}

Experiment-I (Oocyte nuclear maturation). A significant difference $(\mathrm{P}=0.04)$ was noticed in the IVM rates, as the vitrified-thawed oocytes in C solution within the SF and LF groups achieved the highest values compared with the other treated groups, and were second after the control group ( $84.75 \%$ and $85.71 \%$ respectively). Also, by being second after the control group, the oocytes in that group achieved the lowest values of arrest and lyses $(\mathrm{P}=0.04)$ compared with the other treated groups, where the values of arrested oocytes within the SF and LF groups were $15.25 \%$ and $14.29 \%$ respectively, while the rates of lyses were $5.08 \%$ and $5.36 \%$ respectively (Table 1 ).
Across the two follicles groups, the rates of vitrified-thawed oocytes in $\mathrm{C}$ solution which was stopped at the GV stage significantly decreased $(\mathrm{P}=0.02)$ compared with the other treated groups $(12.00 \%$ and $8.33 \%, \mathrm{SF}$ and LF groups respectively), noting that the oocytes in the control group achieved the lowest values $(6.52 \%$ and $6.25 \%$; SF and LF groups respectively). Down to the M-II, the previous group of oocytes (C solution) were second after the control group, achieving the values of $68.00 \%$ and $72.92 \%$ (SF and LF groups) respectively $(\mathrm{P}=0.04)$ (Table 2$)$.

Table 1. Rates of IVM, arrest and lyses of vitrified-thawed Awassi sheep oocytes in different levels of DMSO and EG in addition to the control group

\begin{tabular}{|c|c|c|c|c|c|c|c|c|}
\hline \multirow[b]{2}{*}{ Treatment } & \multirow{2}{*}{$\begin{array}{c}\text { Follicle } \\
\text { size }(\mathrm{mm})\end{array}$} & \multirow{2}{*}{$\begin{array}{c}\text { Incubated } \\
\text { oocytes (No.) }\end{array}$} & \multicolumn{2}{|c|}{ Matured oocytes* } & \multicolumn{2}{|c|}{ Arrest* } & \multicolumn{2}{|c|}{ Lyses* } \\
\hline & & & No. & $\%$ & No. & $\%$ & No. & $\%$ \\
\hline \multirow{2}{*}{ Control } & $\mathrm{SF}^{4}$ & 50 & 46 & $92.00^{\mathrm{a}}$ & 4 & $8.00^{\mathrm{a}}$ & 1 & $2.00^{\mathrm{a}, \mathrm{b}}$ \\
\hline & $\mathrm{LF}^{5}$ & 50 & 48 & $96.00^{\mathrm{a}}$ & 2 & $4.00^{\mathrm{a}}$ & 0 & $0.00^{\mathrm{b}}$ \\
\hline \multirow{2}{*}{$\mathrm{A}^{1}$} & SF & 60 & 46 & $76.67^{\mathrm{b}}$ & 14 & $23.33^{b}$ & 8 & $13.33^{\mathrm{c}}$ \\
\hline & LF & 61 & 47 & $77.05^{\mathrm{b}}$ & 14 & $22.95^{\mathrm{b}}$ & 7 & $11.48^{\mathrm{a}, \mathrm{c}}$ \\
\hline \multirow{2}{*}{$\mathrm{B}^{2}$} & SF & 60 & 47 & $78.33^{\mathrm{b}}$ & 13 & $21.67^{b}$ & 6 & $10.00^{\mathrm{a}, \mathrm{c}}$ \\
\hline & LF & 59 & 46 & $77.97^{\mathrm{b}}$ & 13 & $22.03^{b}$ & 8 & $13.56^{\mathrm{c}}$ \\
\hline \multirow{2}{*}{$\mathrm{C}^{3}$} & SF & 59 & 50 & $84.75^{\mathrm{a}, \mathrm{b}}$ & 9 & $15.25^{\mathrm{a}, \mathrm{b}}$ & 3 & $5.08^{\mathrm{a}, \mathrm{b}, \mathrm{c}}$ \\
\hline & LF & 56 & 48 & $85.71^{\mathrm{a}, \mathrm{b}}$ & 8 & $14.29^{\mathrm{a}, \mathrm{b}}$ & 3 & $5.36^{\mathrm{a}, \mathrm{b}, \mathrm{c}}$ \\
\hline
\end{tabular}

Each subscript letter denotes a subset of treatment categories whose column proportions do not differ significantly from each other at the 0.05 level; * - P $=0.04 ;{ }^{1}$ - DMSO $;^{2}$ - EG; ${ }^{3}$ - DMSO+EG; ${ }^{4}$ - small follicle $(1-2 \mathrm{~mm}) ;{ }^{5}$ - large follicle $(>2 \mathrm{~mm})$.

Table 2. Rates of nuclear maturation stages of vitrified-thawed Awassi sheep oocytes in different levels of DMSO and $\mathrm{EG}$ in addition to the control group

\begin{tabular}{|c|c|c|c|c|c|c|c|c|c|c|}
\hline \multirow[b]{3}{*}{ Treatment } & \multirow{3}{*}{$\begin{array}{c}\text { Follicle } \\
\text { size }(\mathrm{mm})\end{array}$} & \multirow{3}{*}{$\begin{array}{c}\text { Matured } \\
\text { oocytes (No.) }\end{array}$} & \multicolumn{8}{|c|}{ Nuclear maturation phase } \\
\hline & & & \multicolumn{2}{|c|}{$\mathrm{GV}^{* *}$} & \multicolumn{2}{|c|}{ GVBD } & \multicolumn{2}{|r|}{ M-I } & \multicolumn{2}{|c|}{ M-II* } \\
\hline & & & No. & $\%$ & No. & $\%$ & No. & $\%$ & No. & $\%$ \\
\hline \multirow{2}{*}{ Control } & $\mathrm{SF}^{4}$ & 46 & 3 & $6.52^{\mathrm{a}}$ & 3 & 6.52 & 4 & 8.70 & 36 & $78.26^{\mathrm{a}, \mathrm{b}}$ \\
\hline & $\mathrm{LF}^{5}$ & 48 & 3 & $6,25^{\mathrm{a}}$ & 1 & 2.08 & 3 & 6.25 & 41 & $85.42^{b}$ \\
\hline \multirow{2}{*}{$\mathrm{A}^{1}$} & SF & 46 & 11 & $23.91^{\mathrm{b}}$ & 2 & 4.35 & 6 & 13.04 & 27 & $58.70^{\mathrm{c}}$ \\
\hline & LF & 47 & 11 & $23.40^{\mathrm{b}}$ & 3 & 6.38 & 5 & 10.64 & 28 & $59.57^{\mathrm{a}, \mathrm{c}}$ \\
\hline \multirow{2}{*}{$\mathrm{B}^{2}$} & $\mathrm{SF}$ & 47 & 11 & $23.40^{\mathrm{b}}$ & 2 & 4.26 & 6 & 12.77 & 28 & $59.57^{\mathrm{a}, \mathrm{c}}$ \\
\hline & LF & 46 & 6 & $13.04^{\mathrm{a}, \mathrm{b}}$ & 3 & 6.52 & 7 & 15.22 & 30 & $65.22^{\mathrm{a}, \mathrm{c}}$ \\
\hline \multirow{2}{*}{$\mathrm{C}^{3}$} & SF & 50 & 6 & $12.00^{\mathrm{a}, \mathrm{b}}$ & 4 & 8.00 & 6 & 12.00 & 34 & $68.00^{\mathrm{a}, \mathrm{c}}$ \\
\hline & LF & 48 & 4 & $8.33^{\mathrm{A}}$ & 5 & 10.42 & 4 & 8.33 & 35 & $72.92^{\mathrm{a}, \mathrm{b}, \mathrm{c}}$ \\
\hline
\end{tabular}

Each subscript letter denotes a subset of treatment categories whose column proportions do not differ significantly from each other at the 0.05 level; * - P = 0.04; ** - P=0.02; ${ }^{1}$ - DMSO; ${ }^{2}-\mathrm{EG} ;{ }^{3}-\mathrm{DMSO}+\mathrm{EG} ;{ }^{4}$ - small follicle $(1-2 \mathrm{~mm}) ;{ }^{5}-$ large follicle $(>2 \mathrm{~mm})$. 
O. Mardenli et al.: The effect of follicle size and cryoprotectants on nuclear maturation and early embryonic development of vitrified - thawed Awassi sheep oocytes (Ovis aries)

Table 3. Rates of subsequent IVF and cleavage of vitrified-thawed Awassi sheep oocytes in different levels of DMSO and EG in addition to the control group

\begin{tabular}{|c|c|c|c|c|c|c|}
\hline \multirow[b]{2}{*}{ Treatment } & \multirow{2}{*}{$\begin{array}{l}\text { Follicle size } \\
(\mathrm{mm})\end{array}$} & \multirow{2}{*}{$\begin{array}{c}\text { Incubated } \\
\text { oocytes (No.) }\end{array}$} & \multicolumn{2}{|c|}{$\mathrm{IVF}^{* * * *}$} & \multicolumn{2}{|c|}{ Cleavage*** } \\
\hline & & & No. & $\%$ & No. & $\%$ \\
\hline \multirow{2}{*}{ Control } & $\mathrm{SF}^{4}$ & 280 & 196 & $70.00^{\mathrm{a}, \mathrm{b}}$ & 127 & $64.80^{\mathrm{a}, \mathrm{b}}$ \\
\hline & $\mathrm{LF}^{5}$ & 275 & 208 & $75.63^{b}$ & 144 & $69.23^{b}$ \\
\hline \multirow{2}{*}{$\mathrm{A}^{1}$} & $\mathrm{SF}$ & 267 & 132 & $49.43^{c}$ & 62 & $46.97^{\mathrm{c}}$ \\
\hline & $\mathrm{LF}$ & 288 & 154 & $53.47^{\mathrm{c}, \mathrm{d}}$ & 74 & $48.05^{\mathrm{c}}$ \\
\hline \multirow{2}{*}{$\mathrm{B}^{2}$} & SF & 290 & 146 & $50.34^{\mathrm{c}}$ & 70 & $47.95^{\mathrm{c}}$ \\
\hline & $\mathrm{LF}$ & 282 & 157 & $55.67^{\mathrm{c}, \mathrm{d}}$ & 76 & $48.41^{\mathrm{c}}$ \\
\hline \multirow{2}{*}{$\mathrm{C}^{3}$} & $\mathrm{SF}$ & 274 & 166 & $60.58^{\mathrm{a}, \mathrm{c}, \mathrm{d}}$ & 90 & $54.22^{c}$ \\
\hline & LF & 286 & 181 & $63.28^{\mathrm{a}, \mathrm{d}}$ & 104 & $57.46^{\mathrm{a}, \mathrm{c}}$ \\
\hline
\end{tabular}

Each subscript letter denotes a subset of treatment categories whose column proportions do not differ significantly from each other at the 0.05 level; ${ }^{* * *}-\mathrm{P}=0.001 ;{ }^{1}$ - DMSO; ${ }^{2}$ - EG; ${ }^{3}$ - DMSO+EG; ${ }^{4}$ - small follicle $(1-2 \mathrm{~mm}) ;{ }^{5}$ - large follicle $(>2 \mathrm{~mm})$.

Table 4. Rates of subsequent cleavage stages of vitrified-thawed Awassi sheep oocytes in different levels of DMSO and $\mathrm{EG}$ in addition to the control group

\begin{tabular}{|c|c|c|c|c|c|c|c|c|}
\hline \multirow[b]{3}{*}{ Treatment } & \multirow{3}{*}{$\begin{array}{c}\text { Follicle } \\
\text { size }(\mathrm{mm})\end{array}$} & \multirow{3}{*}{$\begin{array}{c}\text { Cleaved } \\
\text { oocytes }\end{array}$} & \multicolumn{6}{|c|}{ Embryonic stage } \\
\hline & & & \multicolumn{2}{|c|}{$2-16$ cell $*$} & \multicolumn{2}{|c|}{ Morula $^{\text {NS }}$} & \multicolumn{2}{|c|}{ Blastocyst $* * * *$} \\
\hline & & & No. & $\%$ & No. & $\%$ & No. & $\%$ \\
\hline \multirow{2}{*}{ Control } & $\mathrm{SF}^{4}$ & 127 & 42 & $33.07^{\mathrm{a}, \mathrm{b}}$ & 39 & 30.71 & 46 & $36.22^{a}$ \\
\hline & $\mathrm{LF}^{5}$ & 144 & 40 & $27.78^{b}$ & 48 & 33.33 & 56 & $38.89^{a}$ \\
\hline \multirow{2}{*}{$\mathrm{A}^{1}$} & $\mathrm{SF}$ & 62 & 29 & $46.77^{\mathrm{a}}$ & 20 & 32.26 & 13 & $20.97^{b}$ \\
\hline & LF & 74 & 34 & $45.95^{\mathrm{a}}$ & 26 & 35.14 & 14 & $18.92^{b}$ \\
\hline \multirow{2}{*}{$B^{2}$} & $\mathrm{SF}$ & 70 & 32 & $45.71^{\mathrm{a}}$ & 23 & 32.86 & 15 & $21.43^{b}$ \\
\hline & LF & 76 & 33 & $43.42^{\mathrm{a}}$ & 23 & 30.26 & 20 & $26.32^{a, b}$ \\
\hline \multirow{2}{*}{$\mathrm{C}^{3}$} & $\mathrm{SF}$ & 90 & 36 & $40.00^{\mathrm{a}, \mathrm{b}}$ & 27 & 30.00 & 27 & $30.00^{\mathrm{a}, \mathrm{b}}$ \\
\hline & $\mathrm{LF}$ & 104 & 42 & $40.38^{a}$ & 31 & 29.81 & 31 & $29.81^{\mathrm{a}, \mathrm{b}}$ \\
\hline
\end{tabular}

Each subscript letter denotes a subset of treatment categories whose column proportions do not differ significantly from each other at the 0.05 level; * $-\mathrm{P}=0.04$; *** $-\mathrm{P}=0.01$; NS - not significant; ${ }^{1}-\mathrm{DMSO} ;{ }^{2}-\mathrm{EG} ;{ }^{3}-\mathrm{DMSO}+\mathrm{EG} ;{ }^{4}-$ small follicle $(1-2 \mathrm{~mm})$; 5 - large follicle $(>2 \mathrm{~mm})$.

Experiment-II.IVF and cleavage stages. Regardless of the superior control group, Table 3 shows that the vitrified- thawed oocytes in C solution achieved high rates of subsequent IVF and cleavage $(\mathrm{P}=0.001)$, as the values of IVF were $60.58 \%$ and $63.28 \%$ (SF and LF groups) respectively, while the values of cleavage rates were $54.22 \%$ and $57.46 \%$ (SF and LF groups) respectively. In contrast, the vitrified- thawed oocytes in A solution achieved the lowest values, as the values of IVF were $49.43 \%$ and $53.47 \%$ (SF and LF groups) respectively, and the values of cleavage rates were $46.97 \%$ and $48.05 \%$ (SF and LF groups) respectively.

Stages of embryos. In the 2-16 cell stage, a clear convergence of rates was observed across the different groups, where the rates ranged between $27.78 \%$ (LF group; control group) and $46.77 \%$ (SF group; A solution); However, a significant decrease $(P=0.04)$ was observed in embryos that stopped at this stage in relation to the group of vitrified thawed oocytes in the participatory solution (C solution), regardless of the control group. 
O. Mardenli et al.: The effect of follicle size and cryoprotectants on nuclear maturation and early embryonic development of vitrified - thawed Awassi sheep oocytes (Ovis aries)

Table 5. Rates of embryos types of vitrified-thawed Awassi sheep oocytes in different levels of DMSO and EG in addition to control group

\begin{tabular}{|c|c|c|c|c|c|c|c|c|}
\hline \multirow[b]{3}{*}{ Treatment } & \multirow{3}{*}{$\begin{array}{c}\text { Follicle } \\
\text { size }(\mathrm{mm})\end{array}$} & \multirow{3}{*}{$\begin{array}{l}\text { Cleaved } \\
\text { oocytes }\end{array}$} & \multicolumn{6}{|c|}{ Embryo type } \\
\hline & & & \multicolumn{2}{|c|}{ Type $1 * * * *$} & \multicolumn{2}{|c|}{ Type $2 * * *$} & \multicolumn{2}{|c|}{ Type 3* } \\
\hline & & & No. & $\%$ & No. & $\%$ & No. & $\%$ \\
\hline \multirow{2}{*}{ Control } & $\mathrm{SF}^{4}$ & 127 & 52 & $40.94^{a}$ & 29 & $22.83^{\mathrm{a}}$ & 46 & $36.22^{\mathrm{a}, \mathrm{b}}$ \\
\hline & $\mathrm{LF}^{5}$ & 144 & 57 & $39.58^{\mathrm{a}, \mathrm{b}}$ & 48 & $33.33^{\mathrm{a}, \mathrm{b}, \mathrm{c}}$ & 39 & $27.08^{\mathrm{a}, \mathrm{b}, \mathrm{c}}$ \\
\hline \multirow{2}{*}{$\mathrm{A}^{1}$} & SF & 62 & 16 & $25.81^{\mathrm{b}, \mathrm{c}, \mathrm{d}}$ & 36 & $58.06^{\mathrm{d}}$ & 10 & $16.13^{c}$ \\
\hline & LF & 74 & 15 & $20.27^{\mathrm{d}}$ & 36 & $48.65^{\mathrm{d}}$ & 23 & $31.08^{\mathrm{a}, \mathrm{b}}$ \\
\hline \multirow{2}{*}{$\mathrm{B}^{2}$} & $\mathrm{SF}$ & 70 & 21 & $30.00^{\mathrm{a}, \mathrm{b}, \mathrm{c}, \mathrm{d}}$ & 33 & $47.14^{\mathrm{c}, \mathrm{d}}$ & 16 & $22.86^{\mathrm{b}, \mathrm{c}}$ \\
\hline & LF & 76 & 18 & $23.68^{\mathrm{c}, \mathrm{d}}$ & 32 & $42.11^{\mathrm{b}, \mathrm{c}, \mathrm{d}}$ & 26 & $34.21^{\mathrm{a}, \mathrm{b}}$ \\
\hline \multirow{2}{*}{$\mathrm{C}^{3}$} & SF & 90 & 33 & $36.67^{\mathrm{a}, \mathrm{b}, \mathrm{c}}$ & 27 & $30.00^{\mathrm{a}, \mathrm{b}}$ & 30 & $33.33^{\mathrm{ab}}$ \\
\hline & LF & 104 & 36 & $34.62^{\mathrm{a}, \mathrm{b}, \mathrm{c}}$ & 28 & $26.92^{a}$ & 40 & $38.46^{\mathrm{a}}$ \\
\hline
\end{tabular}

Each subscript letter denotes a subset of treatment categories whose column proportions do not differ significantly from each other at the 0.05 level; **** $-\mathrm{P}=0.01 ; * * *-\mathrm{P}=0.001 ; *-\mathrm{P}=0.04 ;{ }^{1}{ }^{-} \mathrm{DMSO} ;{ }^{2}-\mathrm{EG} ;{ }^{3}$ - DMSO+EG; ${ }^{4}$ - small follicle $(1-2 \mathrm{~mm}) ;{ }^{5}-$ large follicle $(>2 \mathrm{~mm})$.

As for the blastocyst stage, the rates were much closer between the oocytes of the control group and the oocytes in $\mathrm{C}$ solution. The values were $30.00 \%$ and $29.81 \%$ (SF and LF groups; $\mathrm{C}$ solution) respectively (Table 4).

Embryo quality. Table 5 shows that follicle size and cryoprotectant solution significantly affected the embryo quality. Type 1 embryos derived

\section{Discussion}

The developmental competence of oocytes and cytotoxicity of the $\mathrm{CPA}_{\mathrm{S}}$ are among the most important factors that control the success of subsequent embryo production following oocyte freezing. Otherwise, other factors remain of little effect in that process. It was clear from the results of the current study (Tables 1, 2, 3, 4, and 5) that the Awassi ewe oocytes in the control group were mainly superior in all studied traits compared to the other groups of vitrified oocytes treated with different concentrations of DMSO and EG. The results obtained in this group are considered to be logical, as this group was not subjected to vitrification, or treatment with any of the cryoprotectants. The apparent approximation between the oocytes in $\mathrm{C}$ solution and the control group for the IVM, arrest, lyses, arresting at the GV stage and arrival at the M-II (Tables 1 and 2) can be from vitrified - thawed oocytes in $\mathrm{C}$ solution (SF group) attained the highest values $36.67 \%(\mathrm{P}=$ 0.01 ), while the vitrified - thawed oocytes in A solution (SF group) achieved the highest value of Type 2 embryos $(58.06 \%$; $\mathrm{P}=0.001)$. As for Type 3 embryos, oocytes of the LF group (C solution) achieved the highest rates $(38.46 \% ; \mathrm{P}=0.04)$.

attributed to the arrival of the oocytes at a degree of developmental potential that enables them to continue their nuclear and cytoplasmic maturation stages, especially since the superiority in the rates of the previous traits was in oocytes obtained from follicles (LF group) whose sizes exceeded $2 \mathrm{~mm}$ (CONTI and FRANCIOSI, 2018). In the context of superovulation technology, the primary role of the follicle size is more evident through the close relationship of this factor with hormonal regulation, follicular fluid (FF) and the dominant follicle (dynamic follicular wave), where the study of GRIZELJ et al. (2017) showed a decrease in superovulation rates due to the low numbers of follicles whose sizes ranged between 3.5 and 5.5 $\mathrm{mm}$, and which was positively correlated with the rate of transferable embryos $(r=0.67 ; p<0.05$; the onset of the superovulation protocol). On the other 
hand, the decrease in the values of the previous rates in the vitrified-thawed oocytes (C solution) in comparison with the control group is mainly due to the cryodamage and cytotoxic effect of the DMSO and EG (SZUREK and EROGLU, 2011; LAWSON et al., 2011). The high rates of lyses and arrest in the three groups in our study (Table 1) may also be attributed mainly to the cryodamage of the CPAs, in relation to the remaining quantities of those agents in the oocytes after the processes of rewarming and washing, which have a cytotoxic effect despite their low levels (MOUSSA et al., 2014). Comparing the results of the current study with a study performed by LI et al. (2015) in which a mixture of DMSO and EG was used in vitrification, the IVM rates ranged from $88-92 \%$, while IVF rates ranged from $62-72 \%$. In a study in which the same mixture was used, the IVM, cleavage and blastocyst stages reached $74 \%$, $34 \%$ and $46 \%$ respectively (SHIRAZI et al., 2012). ZHOU et al. (2016) reported the values 65\%, 55\% and $40 \%$ for IVM, IVF and cleavage, respectively. TURATHUM et al. (2010), also reported the values $46.6 \%, 18 \%, 31.5 \%$ and $53 \%$ for GV, GVBD, M-I and $\mathrm{M}-\mathrm{II}$, respectively (DMSO+EG), while the values in the control group were $6.2 \%, 35.4 \%, 50 \%$ and $93.8 \%$, respectively. The data in Table 3 indicate that IVF and cleavage rates exceeded $46 \%$ with the clear superiority of the oocytes in the control group and $\mathrm{C}$ solution ( $\mathrm{SF}$ and LF groups). Moreover, these results can be explained by the effect of the thawing process that the vitrified oocytes passed through, and the average time of equilibrium and vitrification (FERREIRA CHAVES et al., 2014). These previous results may be attributed to the physiological status of the oocytes and their reaction to the chemical behaviour of DMSO and EG during their penetration into the oocytes membranes. In addition, the methods of vitrification, oocyte and early embryo diameter clearly affect the survival rates. By referring to embryo freezing, GRIZELJ et al. (2009) indicated that vitrified mare embryos using the OPS method increased the possibility of embryo transfer, especially those whose diameters were less than $300 \mu \mathrm{m}$. In the current study, it was found that the factor of the follicle size effectively contributed to most of the high rates obtained for the different studied traits, particularly the group of follicles that exceeded $2 \mathrm{~mm}$ (LF group). In this context, major studies have determined the peremptory relationship between follicle size and the developmental competence of the oocytes in relation to oocyte diameter (GILCHRIST and THOMPSON, 2007; KHATIR et al., 2007). In a study conducted by WANI et al. (2013), for the same follicle size groups as in our study, the rates of IVF, cleavage and morula stages reached the values of $79.54 \%, 38.63 \%$ and $19.32 \%$ (SF group), respectively, and $76.75 \%, 58.69 \%$ and $34.13 \%$ (LF group), respectively. Irrespective of the control group, vitrified-thawed oocytes in $\mathrm{C}$ solution achieved higher rates of M-II, IVF, cleavage, blastocyst and Type 1 embryos, compared with the vitifried-thawed oocytes in A and B solutions. In fact, the principles that control the participatory relationship between DMSO and EG are complex and interrelated, but this relationship can be summarized as two basic roles: high permeability and reducing the effect of cytotoxicity. Besides, DMSO reduces electrolytic concentrations in the residual chilled contents within and around cells, while EG alters hydrogen bonding, mixing it with water during cryopreservation (BHATTACHARYA, 2018). Moreover, the significant differences in embryo quality that appeared in the different groups of follicle size and vitrification solutions (Table 5), particularly Type 1 embryos, are also due to a set of factors. The negative role of the cytotoxicity of the CPAs should be mentioned in the efficiency, functioning and progress of meiosis and mitosis divisions (GALEATI et al., 2011), specifically the formation of spindles and the emergence of some fragments that determine the quality of the posterior blastomere embryos (CHAVEZ et al., 2012). The conditions of IVF, paternal age, semen quality and sperm characteristics (motility) may play a role in determining the quality of embryos and their ability for subsequent divisions (SAHA et al., 2014; CHAPUIS et al., 2017). Moreover, the supply of cysteamine as an antioxidant agent $(100 \mu \mathrm{M})$ in the maturation medium positively affects subsequent divisions of matured oocytes (DELEUZE et al., 2010). It is significant that, even within the scope of studies conducted on human oocytes and embryos, which are characterized and distinguished by the 
high accuracy of procedures, there is still wide variability in the outcome of the different types of embryos taken into consideration. In the literature, there seems to be a dearth of studies undertaken to determine the quality of embryos according to morphology, as several studies have gone beyond this indicator and replaced it with the indicator of the pregnancy rate.

\section{Conclusion}

By looking at all the results that were presented in this study, when long-term preservation of oocytes is necessary, it is highly important to collect sheep oocytes during the breeding season, specifically from follicles with diameters greater than $2 \mathrm{~mm}$, and subject them to vitrification according to the protocol: $15 \%$ DMSO and 15\% mL EG, in order to obtain high rates of IVM, IVF, cleavage and Type 1 embryos.

\section{References}

BHATTACHARYA，S. (2018): Cryopretectants and their usage in cryopreservation process. Cryopreservation Biotechnology in Biomedical and Biological Sciences.

DOI: 10.5772/intechopen.80477

CHAPUIS, A., A. GALA, A. FERRIÈRES-HOA, T. MULLET, S. BRINGER-DEUTSCH, E. VINTEJOUX, A. TORRE, S. HAMAMAH (2017): Sperm quality and paternal age: effect on blastocyst formation and pregnancy rates. Basic and Clinical Andrology. 27, 1-9.

DOI: 10.1186/s12610-016-0045-4

CHAVEZ, S. L., K. E. LOEWKE, J. HAN, F. MOUSSAVI, P. COLLS, S. MUNNE, B. BEHR, R. A. REIJO PERA (2012): Dynamic blastomere behaviour reflects human embryo ploidy by the four-cell stage. Nat. Commun. 3 .

DOI: $10.1038 /$ ncomms 2249

CONTI, M., F. FRANCIOSI (2018): Acquisition of oocyte competence to develop as an embryo: integrated nuclear and cytoplasmic events. Hum. Reprod. Update 24, 245266.

DOI: 10.1093/humupd/dmx040

DELEUZE, S., C. DUBOIS, M. CAILLAUD, B. BRUNEAU, G. GOUDET, G. DUCHAMP (2010): Influence of cysteamine on in vitro maturation, in vitro and in vivo fertilization of equine oocytes. Reprod. Domest. Animals. $45,1-7$.

DOI: 10.1111/j.1439-0531.2008.01122.x

FERREIRA CHAVES, D., J. GONÇALVES DE SOUZAFABJAN, P. MERMILLOD, V. JOSÉ, F. FREITAS (2014):
Factors that affect oocyte vitrification in small ruminants. R. Bras. Ci. Vet. 21, 69-75.

DOI: $10.4322 /$ rbcv.2014.025

GALEATI, G., M. SPINACI, C. VALLORANI, D. BUCCI, E. PORCU, C. TAMANINI (2011): Pig oocyte vitrification by cryotop method: Effects on viability, spindle and chromosome configuration and in vitro fertilization. Anim. Reprod. Sci. 127, 43-49.

DOI: 10.1016/j.anireprosci.2011.07.010

GHORBANI, M., R. SADRKHANLOU, V. NEJATI, A. AHMADI, G. TIZROO (2012): The effects of dimethyl sulfoxide and ethylene glycol as vitrification protectants on different cleavage stages of mouse embryo quality. Vet. Res. Forum. 3, 245-249. PMID: 25653766

GILCHRIST, R. B., J. G. THOMPSON (2007): Oocyte maturation: Emerging concepts and technologies to improve developmental potential in vitro. Theriogenology 67, 6-15.

DOI: 10.1016/j.theriogenology.2006.09.027

GRIZELJ, J., G. DUCHAMP, F. GUIGNOT, M. VIDAMET, A. PLOTTO, P. MERMILLOD (2009): Ultra rapid open pulled straw (OPS) vitrification is a perspective for freezing horse embryos. Vet. arhiv 79, 105-117.

GRIZELJ, J., B. ŠPOLJARIĆ, T. DOBRANIĆ, M. LOJKIĆ, F. S. DAVILA, M. SAMARDŽIJA, F. SAMARTZI, I. GETZ, S. VINCE (2017): Efficiency analysis of standard and day 0 superovulatory protocols in Boer breed goats. Vet. arhiv $87,473-486$.

DOI: 10.24099/vet.arhiv.160317

JAVED, M., N. ESFANDIARI, J. SWAIN, E. MICHAEL (2011): Human oocyte cryopreservation - an emerging art technique: are we heading in the right direction? Journal of Reproductive and Stem Cell Biotechnology. 2, 109 -120.

DOI: $10.1177 / 205891581100200205$

KHATIR, H., A. ANOUASSI, A. TIBARY (2007): Effect of follicular size on in vitro developmental competence of oocytes and viability of embryos after transfer in the dromedary (Camelus dromedarius). Anim. Reprod. Sci. 99, 413-420.

DOI: 10.1016/j.anireprosci.2006.06.015

KUWAYAMA, M., O. KATO (2000): All round vitrification of human oocytes and embryos [abstract]. J. Assist. Reprod. Genet. 17,477.

LANE, M., W. B. SCHOOLCRAFT, D. K. GARDNER, D. PHIL (1999): Vitrification of mouse and human blastocysts using a novel cryoloop container-less technique. Fertil. Steril. 72, 1073-1078.

DOI: 10.1016/s0015-0282(99)00418-5

LAWSON, A., H. AHMAD, A. SAMBANIS (2011): Cytotoxicity effects of cryoprotectants as single-component and cocktail vitrification solutions. Cryobiology 62, 115122.

DOI: 10.1016/j.cryobiol.2011.01.012 
O. Mardenli et al.: The effect of follicle size and cryoprotectants on nuclear maturation and early embryonic development of vitrified - thawed Awassi sheep oocytes (Ovis aries)

LI, M., M. M. WANG, H. LIU, K. L. WU, S. Y. MA, C. LI, H. B. ZHAO, Z. J. CHEN (2015): Comparison of the developmental potential and clinical results of in vivo matured oocytes cryopreserved with different vitrification media. Chinese Med. J. 128, 3029-3034.

DOI: $10.4103 / 0366-6999.169052$

MARTINO, A., N. SONGSASEN, S. P. LEIBO (1996): Development into blastocysts of bovine oocytes cryopreserved by Ultra-Rapid Cooling1. Biol. Reprod. 54, 1059-1069.

DOI: 10.1095/biolreprod54.5.1059

MOUSSA, M., J. SHU, X. ZHANG, F. ZENG (2014): Cryopreservation of mammalian oocytes and embryos: current problems and future perspectives. Science China Life Sciences 57, 903-914.

DOI: $10.1007 / \mathrm{s} 11427-014-4689-\mathrm{Z}$

PRENTICE, J. R., M. ANZAR (2011): Cryopreservation of mammalian oocyte for conservation of animal genetics. Veterinary Medicine International. 1-11.

DOI: $10.4061 / 2011 / 146405$

RAJU, G. R., G. PRAKASH, K. KRISHNA, K. MADAN (2007): Meiotic spindle and zona pellucida characteristics as predictors of embryonic development: a preliminary study using PolScope imaging. Reproductive BioMedicine Online. 14, 166-174.

DOI: $10.1016 / \mathrm{s} 1472-6483(10) 60784-5$

SAHA, S., M. A. M. Y. KHANDOKER, L. Y. ASAD, A. M. M. T. REZA, A. HOQUE (2014): Effect of fresh and frozen semen on in vitro fertilization and subsequent development of goat oocytes. Iranian Journal of Applied Animal Science, 4, 325-330.

SALVADOR, I., A. CEBRIAN-SERRANO, D. SALAMONE, M. SILVESTRE (2011): Effect of number of oocytes and embryos on in vitro oocyte maturation, fertilization and embryo development in bovine. Spanish Journal of Agricultural Research 9, 744-752.

DOI: $10.5424 /$ sjar/20110903-374-10

SAS INSTITUTE (2017): SAS/STAT ${ }^{\circledR} 14.3$ User's Guide. Cary, NC 27513 (USA): SAS Institute. https://support.sas. com/documentation/onlinedoc/stat/143/stathpug.pdf

SHIRAZI, A., F. TAHERI, H. NAZARI, M. NORBAKHSHNIA, E. AHMADI, B. HEIDARI (2012): Developmental competence of ovine oocyte following vitrification: effect of oocyte developmental stage, cumulus cells, cytoskeleton stabiliser, FBS concentration, and equilibration time. Zygote 22, 165-173.

DOI: $10.1017 /$ s096719941200038x
SILVA, D., L. P. PEREIRA, R. NAVARRO, D. ROSA, G. PESSOA, C. SILVA, M. RUBIN (2010): In vitro production of Bos taurus indicus embryos with cysteamine. Anim. Reprod. 7, 29-34.

SZUREK, E. A., A. EROGLU (2011): Comparison and avoidance of toxicity of penetrating cryoprotectants. PLoS ONE. 6, e27604.

DOI: 10.1371/journal.pone.0027604

TURATHUM, B., K. SAIKHUN, P. SANGSUWAN, Y. KITIYANANT (2010): Effects of vitrification on nuclear maturation, ultrastructural changes and gene expression of canine oocytes. Reprod. Biol. Endocrinol. 8, 70.

DOI: $10.1186 / 1477-7827-8-70$

VAJTA, G., P. J. BOOTH, P. HOLM, P. GREVE, H. CALLESEN (1997): Successful vitrification of early stage bovine in vitro produced embryos with the open pulled straw (OPS) method. Cryo Letters 18,191-195.

VAJTA, G., P. HOLM, M. KUWAYAMA, P.J. BOOTH, H. JACOBSEN, T. GREVE, H. CALLESEN (1998): Open pulled straw (OPS) vitrification: a new way to reduce cryoinjuries of bovine ova and embryos. Mol. Reprod. Dev. 51,53-8.

WANI, A. R., M. Z. KHAN, K. A. SOFI, A. A. MALIK, F. A. LONE, F. A. BHAT (2013): Effect of follicular size on in vitro maturation, fertilization and culture of sheep embryos. Iranian Journal of Veterinary Research, Shiraz University.14, 299-304.

WINTNER, E. M., A. HERSHKO-KLEMENT, K. TZADIKEVITCH, Y. GHETLER, O. GONEN, O. WINTNER, A. SHULMAN, A. WISER (2017): Does the transfer of a poor quality embryo together with a good quality embryo affect the in vitro fertilization (IVF) outcome? Journal of Ovarian Research 10, 2.

DOI: 10.1186/s13048-016-0297-9

YAVIN, S., A. ARAV (2001): Development of immature bovine oocytes vitrified by the minimum drop size technique and a new vitrification apparatus (VitMaster). Cryobiology 43, 331.

ZHOU, C.-J., D.-H. WANG, X.-X. NIU, X.-W. KONG, Y.-J. LI, J. REN, C.-G. LIANG (2016): High survival of mouse oocytes using an optimized vitrification protocol. Scientific Reports 6.

DOI: $10.1038 /$ srep 19465 
O. Mardenli et al.: The effect of follicle size and cryoprotectants on nuclear maturation and early embryonic development of vitrified - thawed Awassi sheep oocytes (Ovis aries)

Received: 22 April 2020

Accepted: 24 June 2020

\section{MARDENLI, O., M. S. MOHAMMAD AI-KERWI, A. Y. ALOLO: Utjecaj veličine folikula i krioprotektora na sazrijevanje nukleusa i rani embrionalni razvoj odmrznutih oocita ovaca avasi pasmine (Ovis aries). Vet. arhiv 91, 483-493, 2021.}

\section{SAŽETAK}

U ovom su radu provedena dva istraživanja kako bi se proučio utjecaj veličine folikula te dimetil-sulfoksidnih (DMSO) i etilen-glikolnih (EG) krioprotektora na glavne faze sazrijevanja nukleusa (pokus I), te faze brazdanja i kvalitetu embrija (pokus II) oocita u ovaca avasi pasmine. Folikuli su podijeljeni u dvije skupine: mali (SF) $(1-2 \mathrm{~mm})$ i veliki (LF) (>2 mm). Oocite su odmrznute u tri otopine: A (30\% DMSO), B (30 \% EG) i C (15\% DMSO i $15 \%$ EG). U pokusu I oocite odmrznute u otopini $\mathrm{C}$ postigle su najbolje rezultate poslije kontrolne skupine (nezamrznute oocite), budući da su stope sazrijevanja, germinalne vezikule (GV), metafaze II (M-II), zastoja i razgradnje iznosile kako slijedi: $85.71 \%(\mathrm{P}=0.04), 8.33 \%(\mathrm{P}=0.02) 72.92 \%(\mathrm{P}=0.04)$; $\mathrm{LF}$ group, $15.25 \%(\mathrm{P}=0.04)$, and $\mathrm{SF}$ group $5.08 \%(\mathrm{P}=0.04)$. U pokusu II ista je skupina oocita postigla najbolje rezultate poslije kontrolne skupine. Stope oplodnje, dijeljenja stanica, 2 - 16 stanica, tip 3, blastocista, i tip 1 embriji iznosile su kako slijedi: 63,28 \% (P = 0,001), 57,46 \% ( $\mathrm{P}=0,001), 40,38 \%(\mathrm{P}=0,04), 38,46 \%(\mathrm{P}=0,04)$; skupina LF $30,00 \%(\mathrm{P}=0,01)$ i skupina SF 36,67 $\%(\mathrm{P}=0,001)$. Odmrznute oocite u otopini A (skupina $\mathrm{SF}$ ) postigle su najvišu stopu za tip 2 embrij $(58,06 \% ; \mathrm{P}=0,01)$. Nije bilo znakovite razlike u razgradnji gestacijske vrećice (GVBD), metafazi I (M-I) i stadiju morule. Vitrifikacija oocita proizašla iz folikula s promjerom većim od $2 \mathrm{~mm}$ u kombiniranoj otopini DMSO (15\%) i EG (15\%) dovodi do znakovitog porasta u prinosu i kvaliteti dobivenih ovčjih embrija.

Ključne riječi: dimetilni sulfoksid; etilen-glikol; veličina folikula; oocite; ovca; vitrifikacija 
